\title{
Improving sugarcane bagasse quality as ruminant feed with Lactobacillus, cellulase, and molasses
}

\author{
Sarong So, Anusorn Cherdthong* and Metha Wanapat \\ Department of Animal Science, Faculty of Agriculture, Khon Kaen University, Khon Kaen 40002, Thailand
}

Received: Jul 2, 2020

Revised: Jul 31, 2020

Accepted: Aug 4, 2020

${ }^{*}$ Corresponding author Anusorn Cherdthong

Department of Animal Science, Faculty of Agriculture, Khon Kaen University,

Khon Kaen 40002, Thailand.

Tel: +66-43-202-362

E-mail: anusornc@kku.ac.th

Copyright $@ 2020$ Korean Society of Animal Sciences and Technology. This is an Open Access article distributed under the terms of the Creative Commons Attribution Non-Commercial License (http:// creativecommons.org/licenses/by$\mathrm{nc} / 4.0 /$ ) which permits unrestricted non-commercial use, distribution, and reproduction in any medium, provided the original work is properly cited.

ORCID

Sarong So

https://orcid.org/0000-0001-7389-2829

Anusorn Cherdthong

https://orcid.org/0000-0002-8719-4404

Metha Wanapat

https://orcid.org/0000-0002-7633-052X

Competing interests

The authors declare that they have no conflict of interest.

Funding sources

Acknowledge to the Increase

Production Efficiency and Meat Quality of Native Beef and Buffalo Research

Group, KKU, and the Royal Golden Jubilee PhD Program for Asian (Contract No. PHD/0159/2561) and Office of Coordination for Sugarcane and Sugar Research Project (Contract No. RDG62T0081) under Thailand Science Research and Innovation (TSRI), Khon Kaen University (KKU) for providing financial support.

\section{Abstract}

The objective of the study was to evaluate the effects of Lactobacillus, cellulase, and molasses on chemical composition, fermentation qualities, and microorganism count of sugarcane bagasse silage after 30-days fermentation. The treatments were arranged according to a factorial arrangement $(2 \times 2 \times 2)+1$, in a complete randomized design. The first factor consisted of two levels of Lactobacillus casei TH14 (TH14, 0 and $0.05 \mathrm{~g} / \mathrm{kg}$ fresh matter; the second factor consisted of two levels of cellulase enzyme (C, 0 and $10^{4} \mathrm{U} / \mathrm{kg}$ fresh matter); and the third factor consisted of two levels of molasses (M, 0 and $5 \mathrm{~g} / 100 \mathrm{~mL}$ distilled water). A treatment (+1) referred to the use of rice straw without any treatments. The result showed that dry matter increased by $4 \%$ and neutral detergent fiber decreased by $2 \%$ of sugarcane bagasse when ensiled as a combination of additives as compared to untreated sugarcane bagasse. The $\mathrm{pH}$ and ammonia nitrogen were significantly dropped to 3.5 and $2.3 \mathrm{~g} / \mathrm{kg}$ dry matter. Furthermore, lactic acid was increased by $64 \%$ when compared to untreated sugarcane bagasse, respectively. Lactic acid bacteria count was increased by $28 \%$ as compared to untreated sugarcane bagasse. Based on this experiment, fermenting with $L$. casei $\mathrm{TH} 14$, cellulase, and molasses in combination resulted in the promotion of the best qualities of sugarcane bagasse silage.

Keywords: Nutritive value, Lactic acid, Ammonia nitrogen, Butyric acid, Aerobic bacteria

\section{INTRODUCTION}

Sugarcane bagasse is a by-product of the sugar industry after the juice was extracted, approximately 300 $\mathrm{kg}$ of sugarcane bagasse (SB) is produced from the raw sugarcane of one ton [1]. The SB has low protein and high fiber content consisting of less than $3 \%$ crude protein, $40 \%$ to $45 \%$ cellulose, $28 \%$ to $30 \%$ hemicellulose, and $19 \%$ to $21 \%$ lignin [2]. This biomass is potential for ruminant feeding.

Lactic acid bacteria (LAB) fermentation is a well-known technique used to preserve high moist forages under low $\mathrm{pH}$ and high lactic acid conditions from bioconversion of sugar [3,4]. Silage additives such as molasses and cellulase are normally added when low moist and sugar content feedstuffs are fermented with LAB inoculants. Molasses and cellulase greatly affect the growth of LAB by providing more soluble sugars as the substrate for lactic acid production [5]. Current studies have been reported on the effect of LAB and additives for improvement of silages [3,6,7]. Lactobacillus casei TH14 (L. casei TH14) belongs to facultative heterofermentative groups and a local strain isolated from sweet corn sto- 
Acknowledgements

The authors would like to thanks to Tropical

Feed Resources Research and Development

Center (TROFREC) and Department of

Animal Science, Faculty of Agriculture,

Khon Kaen University for research facilities;

Khon Kaen Sugar Industry Public Company

Limited (KSL) for kind support of sugarcane

bagasse.

Availability of data and material

Upon reasonable request, the datasets

of this study can be available from the

corresponding author.

\section{Authors' contributions}

Conceptualization: So S, Cherdthong A

Data curation: So S, Cherdthong A.

Formal analysis: So S.

Methodology: So S, Cherdthong A

Software: So S

Validation: So S, Cherdthong A

Investigation: So S, Cherdthong A.

Writing - original draft: So S.

Writing - review \& editing: So S, Cherdthong A, Wanapat $\mathrm{M}$.

Ethics approval and consent to participate This article does not require IRB/IACUC approval because there are no human and animal participants. ver silage [8], and it has been used for improvement of tropical silage. Khota et al. [5] reported that ensiled sorghum with Lactobacillus plantarum Chikuso 1, L. casei TH 14, and Acremonium cellulase resulting in an increase of $\mathrm{LAB}$ count and lactic acid content and a decrease of $\mathrm{pH}$ and ammonia nitrogen $\left(\mathrm{NH}_{3}-\mathrm{N}\right)$. Few studies on the application of $L$. case $i$ TH14 in combination with additives to improve the nutritive value of high indigestible fiber feedstuffs have been reported. Cherthong et al. [9] revealed that the nutritive value of rice straw was improved with $L$. casei TH14 as inoculant and additives fermentation. However, the study on the effect of $L$. casei TH14, molasses, and cellulase on fermentation characteristics and degradation of nutrients especially the fiber fractions of SB silage has not yet been explored.

Therefore, the study aimed to study the effect of $L$. casei TH14, cellulase, molasses, and their combination of fiber reduction, fermentation products, and microorganism count of SB silage.

\section{MATERIALS AND METHODS}

\section{Sugarcane bagasse}

Sugarcane bagasse was kindly supplied by Khon Kaen Sugar Power Plant, one of the operation plants of Khon Kaen Sugar Industry Public Company Limited (KSL), located in Khon Kaen province, which is one of the major provinces in the Northeastern Thailand and accomodate the four major cities in Isan, Thailand.

\section{Lactobacillus casei TH14, cellulase and molasses}

Commercial L. casei TH14 as a silage starter (composed of 80\% trehalose, $15 \%$ lactose, and 5\% LAB; Bio Ag Khon Kaen, Khon Kaen, Thailand), cellulase enzyme (acid; powder, $5 \times 10^{5} \mathrm{U} / \mathrm{g}$ activity, CAS number: 9004-34-6, Sinobios Imp. \& Exp., Thanghai, China), and molasses were purchased from a local supplier in Khon Kaen province, Thailand, were used.

\section{Treatment and fermentation preparation}

The treatments were arranged according to a factorial arrangement $(2 \times 2 \times 2)+1$, in a complete randomized design (CRD). The first factor consisted of two levels of $L$. casei TH14 (TH14, 0 and $0.05 \mathrm{~g} / \mathrm{kg}$ fresh matter [FM]); the second factor consisted of two levels of cellulase enzyme (C, 0 and $10^{4} \mathrm{U} / \mathrm{kg} \mathrm{FM}$ ); and the third factor consisted of two levels of molasses (M, 0 and $5 \mathrm{~g} / 100 \mathrm{~mL}$ distilled water). A treatment (+1) referred to the use of rice straw without any treatments, which was used for comparison purposes with untreated SB with the addition of distilled water at a respective ratio of 1.5 liters to $1 \mathrm{~kg}$ of FM SB. A total nine treatments were performed: 1) untreated rice straw $(\mathrm{RS},+1), 2)$ untreated SB, 3) treated molasses $(\mathrm{M}), 4)$ treated cellulase $(\mathrm{C}), 5)$ treated TH14 (TH14), 6) treated molasses and cellulase (M:C), 7) treated TH14 and molasses (TH14:M), 8) treated TH14 and cellulase (TH14:C), and 9) treated TH14, cellulase, and molasses (TH14:C:M). A total of $3 \mathrm{~kg}$ of $\mathrm{SB}$ was prepared for all treatments with triplications and was divided into three vacuum bags $(7.5 \times 11$ inch, Zhongshan, China) containing $300 \mathrm{~g}$ of treated SB and sealed using a vacuum sealer machine (Brother, Zhejiang Brother Packing Machinery, Zhejiang, China). The sealed bags were kept at room temperature, and every seven days, three bags from each treatment were opened to assess for the change of $\mathrm{pH}$ and dry matter. The remaining bags were opened on day 30 of fermentation for further analysis, including chemical and biological properties.

\section{Nutritive values analysis}

The chemical composition (dry matter, DM; ash; organic matter, OM; crude protein, CP; ether extract, EE; neutral detergent fiber, NDF; acid detergent fiber, ADF; and lignin) were assessed. 
Raw and fermented at day 30 , the $\mathrm{SB}$ was assessed under an oven at $60^{\circ} \mathrm{C}$, and the particle size was reduced through a $1 \mathrm{~mm}$ mesh screen. The full procedure for assessing DM (viz. 934.01), OM (viz. 942.05), CP (viz. 976.05), EE (viz. 920.39), and ash was mentioned in the AOAC [10] method. A fiber analyzer (ANKOM 200, ANKOM Technology, New York, NY, USA) was used for NDF and $\mathrm{ADF}$ analysis according to the detailed procedure of Van Soest [11], and acid detergent lignin (ADL) analysis was done based on the method of Faichney and White [12]. Also, a bomb calorimeter (AC 500, LECO, St. Joseph, MI, USA) was conducted for the gross energy (GE) analysis of raw and fermented $\mathrm{SB}$ at day 30 .

\section{Fermentation products analysis}

The products at day 30 of fermentation, including $\mathrm{pH}$, lactic acid (LA), acetic acid (AA), propionic acid (PA), butyric acid (BA), $\mathrm{NH}_{3}-\mathrm{N}$, and ethanol, were assessed. The $\mathrm{pH}$ was performed using a $\mathrm{pH}$ meter (HI83141, 0608064N S/N, HANA instruments, Romania), following the procedure mentioned by Chen et al. [3]. High-pressure liquid chromatography (HPLC, Water, and Novapak model 600E, water model I484 UV detector) was performed for organic acid (LA, AA, PA, and $\mathrm{BA}$ ) analysis, with the detailed procedure for LA analysis being described by Pruksatrakul et al. [13]. The AA, PA, and BA analysis followed the procedure of Samuel et al. [14], and the $\mathrm{NH}_{3}-\mathrm{N}$ analysis method was described by Fawcett and Scott [15] using a spectrophotometer (UV/VIS Spectrometer, PG Instruments, London, UK). Gas chromatography (Model HP6890, Hewlett Packard; Headspace, Model HP 7694E, Hewlett Packard; Flame Ionization Detector [FID], Capillary Column HP-1 [Methyl Siloxane], $30 \mathrm{~m}$ length, $320 \mathrm{~nm}$ diameter) was assessed for ethanol concentration following the procedure of Luangkriangkrai [16].

\section{Microorganism counts analysis}

The procedure of Kozaki et al. [17] was used for the biological property assessment. The microorganism assessment was focused on LAB, yeast, mold, aerobic bacteria, and the coliform count. A series of dilutions $\left(10^{-1}, 10^{-2}, 10^{-3}, 10^{-4}\right.$, and $\left.10^{-5}\right)$ were formed for the dilutant of $10 \mathrm{~g}$ of raw and fermented $\mathrm{SB}$ in $90 \mathrm{~mL}$ of sterilized distilled water. The colony counts were enumerated at a selective dilution of $10^{-1}, 10^{-3}$, and $10^{-5}$ and expressed as a log colony form unit per $g$ of FM (Log CFU/ $\mathrm{g}$ FM). The detailed steps are described in the work of Khota et al. [5].

\section{Statistical analysis}

The chemical and biological data were subjected to a $2 \times 2 \times 2(+1)$ factorial in a CRD and analyzed (Window version 6.2.9200, SAS Institute, Cary, NC, USA) with the following model:

$$
Y \mathrm{ijkl}=\mu+\alpha \mathrm{i}+\beta \mathrm{j}+\gamma \mathrm{k}+\alpha \beta \mathrm{ij}+\alpha \gamma \mathrm{ik}+\beta \gamma \mathrm{jk}+\alpha \beta \gamma \mathrm{ijk}+\varepsilon \mathrm{ijkl}
$$

Where Yijkl = observation values of treatment combination at $\mathrm{ijk}$, replication 1 when $1=1, \ldots, \mathrm{r}, \mu=$ overall mean; $\alpha i=$ effect of main effect $A$ at $i$ when $i=1, \ldots, a ; \beta j=$ effect of main effect $B$ at $j$ when $\mathrm{j}=1, \ldots, \mathrm{b} ; \gamma \mathrm{k}=$ effect of main effect $\mathrm{C}$ at $\mathrm{k}$ when $\mathrm{k}=1, \ldots, \mathrm{c} ; \alpha \beta \mathrm{ij}=$ interaction of $\mathrm{A}$ and $\mathrm{B}$ at $\mathrm{ij}$; $\alpha \gamma \mathrm{ik}=$ interaction of $\mathrm{A}$ and $\mathrm{C}$ at $\mathrm{ik} ; \beta \gamma \mathrm{jk}=$ interaction of $\mathrm{B}$ and $\mathrm{C}$ at $\mathrm{jk} ; \alpha \beta \gamma \mathrm{ijk}=$ overall interaction of $\mathrm{A}, \mathrm{B}$, and $\mathrm{C}$ at ijk; and $\varepsilon \mathrm{ijk} \mathrm{l}=$ error term. The means difference was compared using Duncan's new multiple range tests [18] at $p<0.05$, which is considered to be a statistical difference. Also, orthogonal contrasts were performed to study the difference of each factor. 


\section{RESULTS}

\section{Nutritive values}

Table 1 shows the nutritive values of raw and fermented SB. The raw SB was composed of 785.3 $\mathrm{g} / \mathrm{kg}$ of DM, $72.2 \mathrm{~g} / \mathrm{kg}$ of ash, $927.8 \mathrm{~g} / \mathrm{kg}$ of OM, $26.7 \mathrm{~g} / \mathrm{kg}$ of CP, $3.1 \mathrm{~g} / \mathrm{kg}$ of EE, $744.7 \mathrm{~g} / \mathrm{kg}$ of $\mathrm{NDF}, 689.6 \mathrm{~g} / \mathrm{kg}$ of ADF, and $142.9 \mathrm{~g} / \mathrm{kg}$ of ADL, respectively. The GE was $6.93 \mathrm{kcal} / \mathrm{g}$ of FM (described in Table 1). The DM (306.4-317.7 g/ $\mathrm{kg}$ of DM), NDF (773.0-721.6 g/ $\mathrm{kg}$ of DM), and $\mathrm{GE}(7.20-7.31 \mathrm{kcal} / \mathrm{g}$ of $\mathrm{FM})$ after 30 days of fermentation were significantly different among treatments, whereas OM (935.97-933.59 g/kg of DM), ash (64.03-66.41 g $/ \mathrm{kg}$ of DM), ADF $(601.15-641.62 \mathrm{~g} / \mathrm{kg}$ of DM), and ADL (110.28-138.53 g/kg of DM) were not significant $(p$ > $0.005)$ among treatments. The SB and RS treatments differed significantly in terms of $\mathrm{OM}$, ash, $\mathrm{ADF}$, and $\mathrm{ADL}$ values.

\section{Fermentation products}

Fig. 1 shows the $\mathrm{pH}$ change of un-inoculated $\mathrm{RS}$, un-inoculated SB, and inoculated SB during fermentation on days $0,7,14,21$, and 30 . Table 2 shows the products of fermented SB after 30 days, including $\mathrm{pH}(<5)$, LA (14.3-78.7 $\mathrm{g} / \mathrm{kg}$ of DM), AA (10.80-24.14 g/kg of DM), PA (not detected), BA (not detected), $\mathrm{NH}_{3}-\mathrm{N}$ (3.7-2.3 g/kg of DM), and ethanol (12.7-10.3 $\mathrm{g} / \mathrm{kg}$ of DM). The

Table 1. Nutritive values of rice straw and sugarcane bagasse after 30 days of fermentation

\begin{tabular}{|c|c|c|c|c|c|c|c|c|c|}
\hline \multirow{2}{*}{ Items } & \multirow{2}{*}{ DM } & Ash & OM & $\mathbf{C P}$ & EE & NDF & ADF & ADL & \multirow{2}{*}{$\begin{array}{c}\mathrm{GE} \\
(\mathrm{kcal} / \mathrm{g})\end{array}$} \\
\hline & & \multicolumn{7}{|c|}{ - } & \\
\hline RSB & 785.3 & 72.2 & 927.8 & 26.7 & 3.1 & 744.7 & 689.6 & 142.9 & 6.93 \\
\hline RS & $306.4^{\mathrm{bc}}$ & $64.03^{\mathrm{b}}$ & $935.97^{\mathrm{a}}$ & 23.8 & 3.2 & $773.0^{\mathrm{a}}$ & $601.15^{\mathrm{b}}$ & $110.28^{b}$ & 7.20 \\
\hline SB & $304.0^{\mathrm{bc}}$ & $66.82^{\mathrm{a}}$ & $933.19^{b}$ & 25.6 & 3.0 & $737.7^{\mathrm{b}}$ & $641.74^{\mathrm{a}}$ & $139.57^{\mathrm{a}}$ & 7.07 \\
\hline M & $305.3^{\mathrm{bc}}$ & $66.51^{\mathrm{a}}$ & $933.49^{b}$ & 26.2 & 3.2 & $736.9^{b}$ & $641.77^{\mathrm{a}}$ & $138.67^{a}$ & 7.18 \\
\hline C & $302.6^{c}$ & $66.56^{\mathrm{a}}$ & $933.44^{b}$ & 25.7 & 3.3 & $729.5^{c}$ & $641.69^{\mathrm{a}}$ & $138.26^{\mathrm{a}}$ & 7.14 \\
\hline TH14 & $307.7^{\mathrm{b}}$ & $67.43^{\mathrm{a}}$ & $932.57^{b}$ & 26.8 & 3.0 & $736.6^{\mathrm{b}}$ & $641.68^{\mathrm{a}}$ & $138.81^{a}$ & 7.10 \\
\hline$M: C$ & $308.1^{b}$ & $66.31^{a}$ & $933.69^{b}$ & 26.1 & 3.5 & $724.5^{\mathrm{cd}}$ & $641.63^{\mathrm{a}}$ & $138.60^{\mathrm{a}}$ & 7.24 \\
\hline TH14:M & $316.7^{\mathrm{a}}$ & $67.57^{\mathrm{a}}$ & $932.44^{b}$ & 27.2 & 3.4 & $736.2^{\mathrm{b}}$ & $641.77^{\mathrm{a}}$ & $139.17^{\mathrm{a}}$ & 7.17 \\
\hline TH14:C & $314.9^{\mathrm{a}}$ & $66.45^{\mathrm{a}}$ & $933.55^{b}$ & 26.4 & 3.3 & $725.4^{c}$ & $641.66^{a}$ & $138.23^{a}$ & 7.16 \\
\hline TH14:M:C & $317.7^{\mathrm{a}}$ & $66.41^{\mathrm{a}}$ & $933.59^{b}$ & 28.2 & 3.7 & $721.6^{d}$ & $641.62^{\mathrm{a}}$ & 138.53 & 7.31 \\
\hline SEM & 0.10 & 0.330 & 0.33 & 0.36 & 0.02 & 0.11 & 0.09 & 0.28 & 0.05 \\
\hline \multicolumn{10}{|l|}{ Orthogonal contrasts } \\
\hline RS vs SB & 0.247 & 0.002 & 0.002 & 0.758 & 0.411 & $<.000$ & $<.000$ & $<.000$ & 0.293 \\
\hline TH14 (No vs Yes) & $<.000$ & 0.245 & 0.245 & 0.733 & 0.316 & 0.086 & 0.793 & 0.755 & 0.693 \\
\hline C (No vs Yes) & 0.049 & 0.084 & 0.084 & 0.968 & 0.076 & $<.000$ & 0.356 & 0.048 & 0.184 \\
\hline M (No vs Yes) & 0.001 & 0.738 & 0.738 & 0.834 & 0.089 & 0.060 & 0.356 & 0.935 & 0.101 \\
\hline \multicolumn{10}{|l|}{ Interaction effect } \\
\hline $\mathrm{TH} 14 \times \mathrm{C}$ & 0.050 & 0.265 & 0.2653 & 0.970 & 0.861 & 0.000 & 0.674 & 0.856 & 0.048 \\
\hline $\mathrm{TH} 14 \times \mathrm{M}$ & 0.132 & 0.656 & 0.6555 & 0.935 & 0.703 & 0.109 & 0.165 & 0.178 & 0.872 \\
\hline$C \times M$ & 0.510 & 0.934 & 0.9339 & 0.945 & 0.958 & $<.000$ & 0.001 & 0.194 & 0.072 \\
\hline $\mathrm{TH} 14 \times \mathrm{C} \times \mathrm{M}$ & 0.012 & 0.874 & 0.8738 & 0.920 & 0.999 & 0.360 & 0.531 & 0.157 & 0.017 \\
\hline
\end{tabular}

${ }^{a-d}$ Means with different superscript lowercase letter within column showed statistically $(p<0.05)$ different of the treatments.

DM, dry matter; OM, organic matter; CP, crude protein; EE, ether extract; NDF, neutral detergent fiber; ADF, acid detergent fiber; ADL, acid detergent lignin; GE, gross energy; RSB, raw sugarcane bagasse; RS, untreated rice straw; SB, untreated sugarcane bagasse; $M$, fermented with molasses; $C$, fermented with cellulase; $T H 14$, fermented with $L$. casei TH14; $\mathrm{M}: \mathrm{C}$, fermented with molasses and cellulase; TH14:M, fermented with $L$. casei TH14 and molasses; TH14:C, fermented with $L$. casei TH14 and cellulase enzyme; TH14:M:C, fermented with $L$. casei $\mathrm{TH} 14$; molasses and cellulase. 
Table 2. Fermentation products of rice straw and sugarcane bagasse after 30 days of fermentation

\begin{tabular}{|c|c|c|c|c|c|c|c|}
\hline \multirow{2}{*}{ Items } & \multirow{2}{*}{$\mathrm{pH}$} & LA & AA & PA & BA & $\mathrm{NH}_{3}-\mathrm{N}$ & Ethanol \\
\hline & & \multicolumn{6}{|c|}{ 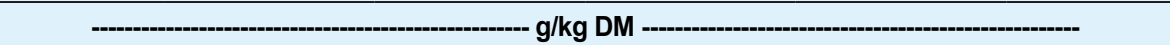 } \\
\hline RS & $4.67^{\mathrm{a}}$ & $14.3^{9}$ & $10.80^{9}$ & ND & ND & $3.7^{\mathrm{a}}$ & $12.7^{\mathrm{ab}}$ \\
\hline SB & $4.03^{b}$ & $27.6^{f}$ & $11.27^{f}$ & ND & ND & $3.6^{\mathrm{a}}$ & $11.2^{\mathrm{ab}}$ \\
\hline M & $3.58^{\mathrm{d}}$ & $41.3^{\mathrm{e}}$ & $13.54^{\mathrm{e}}$ & ND & ND & $3.8^{\mathrm{a}}$ & $13.6^{\mathrm{a}}$ \\
\hline $\mathrm{C}$ & $4.05^{\mathrm{b}}$ & $40.3^{\mathrm{e}}$ & $13.97^{\mathrm{de}}$ & ND & ND & $3.6^{\mathrm{a}}$ & $11.8^{\mathrm{ab}}$ \\
\hline TH14 & $4.03^{b c}$ & $58.0^{d}$ & $14.10^{d}$ & ND & ND & $3.5^{\mathrm{a}}$ & $10.4^{\mathrm{b}}$ \\
\hline $\mathrm{M}: \mathrm{C}$ & $3.53^{\mathrm{e}}$ & $41.6^{\mathrm{e}}$ & $13.84^{\mathrm{de}}$ & ND & ND & $3.8^{\mathrm{a}}$ & $11.8^{\mathrm{ab}}$ \\
\hline TH14:M & $3.52^{\mathrm{e}}$ & $73.1^{\mathrm{b}}$ & $17.28^{\mathrm{b}}$ & ND & ND & $3.2^{\mathrm{b}}$ & $10.4^{\mathrm{b}}$ \\
\hline TH14:C & $3.99^{\mathrm{C}}$ & $68.9^{\mathrm{c}}$ & $15.72^{c}$ & ND & ND & $3.0^{\mathrm{b}}$ & $10.2^{b}$ \\
\hline TH14:M:C & $3.50^{\mathrm{e}}$ & $78.7^{\mathrm{a}}$ & $24.14^{\mathrm{a}}$ & ND & ND & $2.3^{c}$ & $10.3^{b}$ \\
\hline SEM & 0.010 & 0.030 & 0.090 & - & - & 0.010 & 0.050 \\
\hline \multicolumn{8}{|l|}{ Orthogonal contrast } \\
\hline RS vs SB & $<.000$ & $<.0001$ & 0.033 & & & 0.590 & 0.202 \\
\hline TH14 (No vs Yes) & 0.000 & $<.0001$ & $<.0001$ & - & - & $<.0001$ & 0.009 \\
\hline C (No vs Yes) & 0.052 & $<.0001$ & $<.0001$ & - & - & 0.001 & 0.513 \\
\hline M (No vs Yes) & $<.000$ & $<.0001$ & $<.0001$ & & & 0.013 & 0.278 \\
\hline \multicolumn{8}{|l|}{ Interaction effect } \\
\hline $\mathrm{TH} 14 \times \mathrm{C}$ & 0.410 & 0.023 & $<.000$ & - & - & 0.0011 & 0.4992 \\
\hline $\mathrm{TH} 14 \times \mathrm{M}$ & 0.520 & $<.000$ & $<.000$ & - & - & 0.0029 & 0.1100 \\
\hline$C \times M$ & 0.239 & $<.000$ & 0.000 & - & - & 0.241 & 0.0994 \\
\hline $\mathrm{TH} 14 \times \mathrm{C} \times \mathrm{M}$ & 0.032 & 0.001 & $<.000$ & - & - & 0.1575 & 0.0812 \\
\hline
\end{tabular}

${ }^{a-g}$ Means with a different superscript lowercase letter within column showed statistically $(p<0.05)$ different from the treatments.

LA, lactic acid; $\mathrm{AA}$, acetic acid; PA, propionic acid; $\mathrm{BA}$, butyric acid; $\mathrm{NH}_{3}-\mathrm{N}$, ammonia nitrogen; $\mathrm{DM}$, dry matter; $\mathrm{RS}$, untreated rice straw; $\mathrm{ND}$, not detected; SB, untreated sugarcane bagasse; $M$, fermented with molasses; $C$, fermented with cellulase; $\mathrm{TH} 14$, fermented with $L$. casei TH14; M:C, sugarcane bagase fermented with molasses and cellulase; TH14:M, fermented with $L$. casei $\mathrm{TH} 14$ and molasses; TH14:C, fermented with $L$. casei TH14 and cellulase enzyme; TH14:M:C, fermented with $L$. casei TH14; molasses, and cellulase.

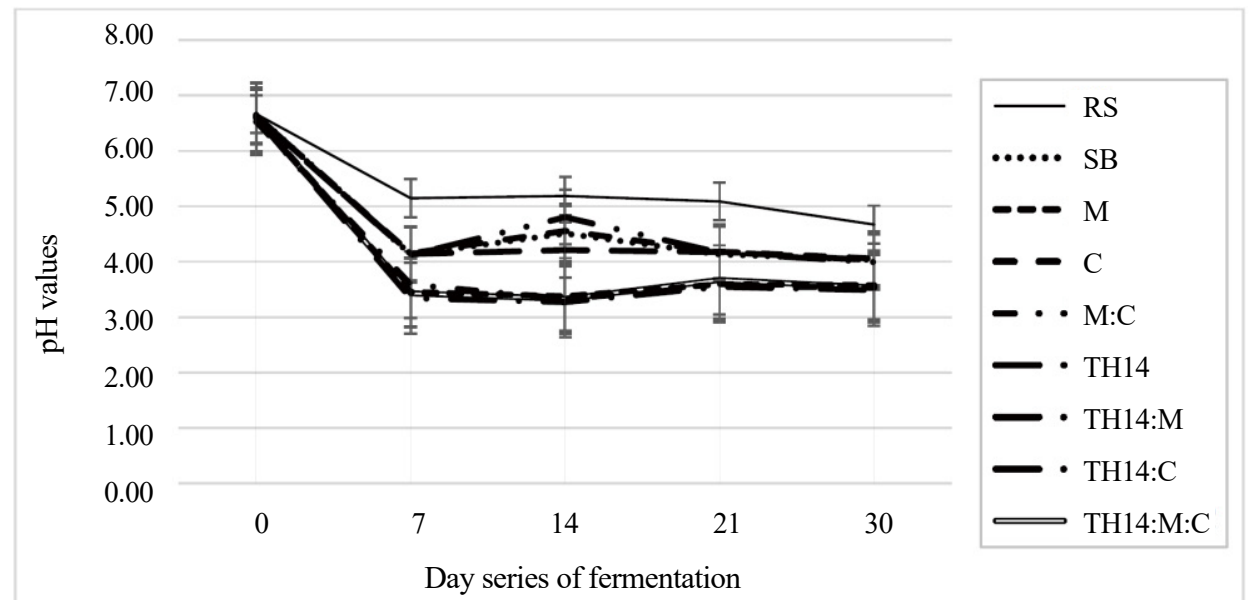

Fig. 1. The change of $\mathrm{pH}$ in fermented rice straw and sugarcane bagasse during a day-series of fermentation. RS, untreated rice straw; SB, untreated sugarcane bagasse; $M$, fermented with molasses; $C$, fermented with cellulase; M:C, fermented with molasses and cellulase; TH14, fermented with $L$. casei TH14; TH14:M, fermented with $L$. casei $\mathrm{TH} 14$ and molasses; TH14:C, fermented with $L$. casei $\mathrm{TH} 14$ and cellulase; TH14:M:C, fermented with $L$. casei TH14, molasses, and cellulase. 
$\mathrm{pH}, \mathrm{LA}, \mathrm{AA}, \mathrm{NH}_{3}-\mathrm{N}$, and ethanol values were significantly $(p<0.05)$ different among treatments, whereas the $\mathrm{BA}$ and $\mathrm{PA}$ values were not detected in the current work. The $\mathrm{pH}, \mathrm{LA}$, and $\mathrm{AA}$ values were significantly different between $\mathrm{SB}$ and $\mathrm{RS}$ treatments.

\section{Microorganism counts}

The microorganism count in raw SB was $4.93 \mathrm{Log} \mathrm{CFU} / \mathrm{g}$ of LAB, 5.20 Log CFU/g of yeast, 2.69 Log CFU/g of molds, 5.69 Log CFU/g of aerobic bacteria, and 3.87 Log CFU/g of FM of coliform (described in Table 3). After 30 days of fermentation, the microorganism count was 3.47-7.91 Log CFU/g FM of LAB, 4.63-3.96 Log CFU/g of FM of yeast, and 6.19-4.45 Log CFU/g of FM of aerobic bacteria. The LAB, yeast, and aerobic bacteria count differed significantly among treatments. The mold and coliform counts were not detected in the current work. The LAB, yeast, and aerobic bacteria counts were different between the RS and SB treatments (Table 3).

\section{DISCUSSION}

\section{Nutritive values}

The DM contents were in the range of approximately 302 to $317 \mathrm{~g} / \mathrm{kg} \mathrm{DM}$, which was the proper range for fermentation [19], for long-term storage and for inhibiting unfriendly microorganisms [20]. DM was increased by $4 \%$ compared to untreated SB when fermented with TH14, cellulase,

Table 3. Microorganism counts of rice straw and sugarcane bagasse after 30 days of fermentation

\begin{tabular}{|c|c|c|c|c|c|}
\hline \multirow{2}{*}{ Items } & \multicolumn{5}{|c|}{ Microorganism count (Log CFU/g FM) after 30 days of fermentation } \\
\hline & LAB & Yeast & Mold & Aerobic & Coliform \\
\hline RS & $3.47^{e}$ & $4.63^{\mathrm{a}}$ & ND & $6.19^{a}$ & 3.58 \\
\hline SB & $5.69^{d}$ & $4.18^{\mathrm{b}}$ & ND & $5.23^{\mathrm{c}}$ & ND \\
\hline M & $6.67^{c}$ & $4.14^{\mathrm{bc}}$ & ND & $5.30^{\mathrm{bc}}$ & ND \\
\hline $\mathrm{C}$ & $6.05^{\mathrm{d}}$ & $4.16^{\mathrm{bc}}$ & ND & $5.34^{\mathrm{bc}}$ & ND \\
\hline $\mathrm{M}: \mathrm{C}$ & $6.75^{\mathrm{c}}$ & $4.14^{\mathrm{bc}}$ & ND & $5.39^{\mathrm{a}}$ & ND \\
\hline TH14 & $7.23^{\mathrm{bc}}$ & $4.12^{\mathrm{c}}$ & ND & $4.65^{d}$ & ND \\
\hline TH14:M & $7.51^{\mathrm{ab}}$ & $4.11^{\mathrm{d}}$ & ND & $4.62^{d}$ & ND \\
\hline TH14:C & $7.34^{\mathrm{ab}}$ & $3.98^{\mathrm{c}}$ & ND & $4.64^{d}$ & ND \\
\hline TH14:M:C & $7.91^{\mathrm{a}}$ & $3.96^{\mathrm{d}}$ & ND & $4.45^{\mathrm{e}}$ & ND \\
\hline SEM & 0.120 & 0.010 & - & 0.030 & - \\
\hline \multicolumn{6}{|l|}{ Orthogonal contrasts } \\
\hline RS vs SB & $<.000$ & $<.000$ & - & 0.329 & - \\
\hline TH14 (No vs Yes) & $<.000$ & $<.000$ & - & 0.298 & - \\
\hline C (No vs Yes) & 0.088 & 0.395 & - & 0.091 & - \\
\hline M (No vs Yes) & 0.00 & $<.000$ & - & 0.096 & - \\
\hline \multicolumn{6}{|l|}{ Interaction effect } \\
\hline $\mathrm{TH} 14 \times \mathrm{C}$ & 0.885 & 0.976 & - & 0.001 & - \\
\hline $\mathrm{TH} 14 \times \mathrm{M}$ & 0.146 & 0.001 & - & 0.003 & - \\
\hline $\mathrm{C} \times \mathrm{M}$ & 0.983 & 0.698 & - & 0.048 & - \\
\hline $\mathrm{TH} 14 \times \mathrm{C} \times \mathrm{M}$ & 0.302 & 0.613 & - & 0.083 & - \\
\hline
\end{tabular}

The microorganism count presented in raw sugarcane bagasse was $4.93 \mathrm{LAB}, 5.20$ yeast, 2.69 molds, 5.69 aerobic bacteria, and $3.87 \mathrm{Log}$ CFU/g FM.

${ }^{\mathrm{a}-\mathrm{e}}$ Means with different superscript lowercase letters within column showed statistically $(p<0.05)$ different from the effect of the treatment compared to RS.

CFU, colony form unit; FM, fresh matter; LAB, lactic acid bacteria; RS, untreated rice straw; ND, not detected; SB, untreated sugarcane bagasse; M, fermented with molasses; C, fermented with cellulase; M:C, fermented with molasses and cellulase; TH14, fermented with $L$. casei TH14; TH14:M, fermented with $L$. casei TH14 and molasses; TH14:C, fermented with L. casei TH14 and cellulase; TH14:M:C, fermented with $L$. casei TH14, molasses, and cellulase. 
and molasses. This increase was due to the action of cellulase enzyme in breaking down the cell wall and releasing more soluble carbohydrates and molasses as an additional nutrient supply. This also was available for $\mathrm{LAB}$ fermentation resulting in $\mathrm{pH}$ reduction and $\mathrm{DM}$ loss prevention [21,22]. This finding was similar to the report of Chen et al. [3], who reported that fermented sugarcane tops with $\mathrm{LAB}$, molasses, and cellulase that resulted significantly in increasing the DM content when fermented with $\mathrm{LAB}$ and molasses, but this content decreased with cellulase treatment. Also, $\mathrm{Li}$ et al. [7] reported that the DM increased in most varieties of rice straw when fermented with $\mathrm{LAB}$, except for the Zhenxian96 breed. However, SB fermented with cellulase as an additive had a significantly $(p<0.05)$ lower DM compared with other treatments. The reason for this significant change could be the action of cellulase as the main factor in breaking down the cell wall components, failing to form a maximum LAB count, and the growth of yeast and aerobic bacteria. Other findings were similarly reported [3,23-25], with other researchers discovering a reduction in the $\mathrm{DM}$ of fermented materials when treated with an enzyme. The reasons could be due to the application of an enzyme positively responded to the ensiled SB due to its low water-soluble carbohydrate content, and it subsequently improved fermentation using a released substrate [26]. The $\mathrm{CP}$ and EE contents of fermented SB failed to differ $(p>0.05)$ when compared with untreated SB and RS, which was similarly reported by Kim et al. [27], who found that various strains of Lactobacillus plantarum did not affect the $\mathrm{CP}$ content of rice straw silage.

A variety of enzymes were purposely added to ensiled fibrous materials to decrease the indigestible components and enhance the nutritive value. This mainly released more soluble carbohydrates and later enabled $\mathrm{LAB}$ to produce lactic acid. The NDF, ADF, and ADL values in fermented $\mathrm{SB}$ were lower than in the SB treatment (Table 1). The NDF was decreased by $2 \%$ when compared to untreated SB when fermented with a combination of TH14, cellulase, and molasses. Enzymes were often added with a variety of bacterial inoculations. Thus, the responses to fermented materials were to either enzymes or bacterial inoculations [21]. Some works have interpreted that this combination positively and synergistically improved fermented material quality, which resulted in more soluble carbohydrates, and further improves feed efficiency [28]. Notably, the response of enzyme utilization in anaerobic fermentation was positive and suitable for fibrous materials with less water-soluble carbohydrates (WSC). Gado et al. [25] found that fiber fraction and DM biological degradation were enhanced with enzyme cocktails during anaerobic fermentation.

The GE was significantly $(p<0.05)$ increased by the interaction of TH14, cellulase, and molasses. The combination of additives contributed to a higher GE value when compared with added additive alone and untreated treatments. This increase could be described by the contribution of molasses providing highly available soluble carbohydrates as an energy source, and the action of cellulase on the outer components released more usable carbohydrates. Moreover, Derwhust et al. [29] stated that organic acid output in the fermented materials contributed mainly to the increase of GE, approximately 10\%-14\%, in which BA represented $24.93 \mathrm{MJ} / \mathrm{kg}$ of DM, and LA represented $15.16 \mathrm{MJ} / \mathrm{kg}$ of DM in terms of the GE value. The recent finding was in agreement with McDonald et al. [30], who reported that fermented materials had a higher GE value compared with fresh materials.

\section{Fermentation products}

Anaerobic fermentation or silage, a method of forage crops, byproducts, and grass preservation, was practiced as well [31]. The process happened without the presence of oxygen and is characterized by an increasing $\mathrm{LAB}$ number and decreasing $\mathrm{pH}$ [32]. A rapidly decreasing $\mathrm{pH}$ could preserve ensiled materials longer. Also, the loss of nutrients was not significant [33]. The $\mathrm{pH}$ and $\mathrm{NH}_{3}-\mathrm{N}$ were significantly dropped to 3.5 and $2.3 \mathrm{~g} / \mathrm{kg}$ DM. Moreover, LA and AA were increased by $64.93 \%$ 
and 53.31\% compared to untreated SB, which found in the treatment combination of TH14, cellulase, and molasses, respectively. After 30 days under anaerobic fermentation, the acidity of fermented SB became more acid (4.03-3.5) compared with the raw SB. The $\mathrm{pH}$ after fermentation dropped significantly under the interaction of the combination of the three additives. This implied that the combination had a positive synergistic effect on the acidity of the fermented materials. The dropping of the $\mathrm{pH}$ was due to the increase of $\mathrm{LA}$ and $\mathrm{AA}$ values. These values were considerably high in treatments fermented with TH14 inoculation, with the highest LA $(78.70 \mathrm{~g} / \mathrm{kg}$ of DM) and AA (24.14 g/kg of DM) values being found in the treatments fermented with TH14, C, and $\mathrm{M}$. This increase was mainly dominated by the increase in the LAB count, ranging from 3.47-7.91 Log CFU/g of FM. Molasses and cellulase addition supplied more direct and indirect substrates for promoting the anaerobic fermentation resulting in a high LA concentration and LAB count $[34,35]$. Adding these additives promoted better qualities when compared with no additives and indicated a successful fermentation process for SB. This addition was the most suitable for SB fermentation to succeed due to its low WSC value; in spite of this, it would not be necessary for materials with high WSC values [35]. The AA concentration was increased significantly in response to additives compared with the SB treatment, and the highest value of $24.14 \mathrm{~g} / \mathrm{kg}$ of DM was found in the treatment of TH14, cellulase, and molasses. This increase could be due to the slow sealing process since it was naturally produced in silage. The slow sealing process could be an advantage of enterobacteria and heterolactic-bacteria growth resulting in the accumulation of the AA concentration [36]. Another reason could be the high ambient temperature during storage increasing the AA concentration [37] with the presence of Lactobacillus buchneri growth [38]. The AA directly affected the yeast and mold growth on an opening day at the end of fermentation [21]. The $\mathrm{NH}_{3}-\mathrm{N}(3.7-2.3 \mathrm{~g} / \mathrm{kg}$ $\mathrm{DM})$ and ethanol (12.7-10.3 $\mathrm{g} / \mathrm{kg} \mathrm{DM})$ concentrations were significantly reduced when compared with the $\mathrm{SB}$ treatment, while the lowest values of $\mathrm{NH}_{3}-\mathrm{N}$ and ethanol were found in the treatment of TH14, cellulase, and molasses. This decrease could be due to the increase in the LAB count, LA concentration, and $\mathrm{AA}$ concentration, as well as the decline in the $\mathrm{pH}$, which depressed the action of Clostridia and other microorganisms, including yeast and mold. The presence of Clostridia affected the protein content in the fermented material by degrading to $\mathrm{NH}_{3}-\mathrm{N}$ [39]. The $\mathrm{PA}$ and $\mathrm{BA}$ concentrations were not detected; even though, mold and coliform were not found in this work.

\section{Microorganism count}

Regarding evaluating the quality of anaerobic fermentation, $\mathrm{pH}$ is always viewed as the important consideration factor [40]. Naturally, epiphytic LAB is present in almost all living plants and contributed mainly to the fermentation process, where the fermented materials were considered to be well preserved at a count number of $5 \mathrm{Log}$ CFU/g of FM [41,42]. The LAB count was significantly increased by $28 \%$ as compared to untreated $\mathrm{SB}$, and the non-important bacteria in the fermentation process was inhibited. An increase of $\mathrm{LAB}$ count could be explained by the physiological growth of $\mathrm{LAB}$ and the adequate supply of molasses as a substrate. Homofermentative LAB isolated in the tropical area normally could grow well under $\mathrm{pH}$ less than 4 , and during the first stage of fermentation, while LAB could grow fast with an adequate amount of WSC $[8,43]$. L. casei TH14 was one of homo-fermentative $\mathrm{LAB}$ which may grow well under $\mathrm{pH} 4$ when compared to other epiphytic $\mathrm{LAB}$ and produced high lactic acid concentration with lowering the $\mathrm{pH}$ value.

\section{CONCLUSION}

The current study could be concluded that additives could enhance the biochemical qualities of SB when compared to untreated SB and RS. Fermenting with $L$. casei TH14, cellulase and molasses 
in combination resulted in the promotion of high quality of SB with DM loss prevention, fiber component reduction, $\mathrm{pH}$ reduction, and enhanced LA production and LAB count. Further studies both in vitro and in vivo are recommended to elucidate the effect of fermented SB on nutrients digestibility and rumen fermentation.

\section{REFERENCES}

1. Inácio JG, Ferreira MA, Silva RC, Silva JL, Oliveira JCV, Santos DC, et al. Sugarcane bagasse as exclusive roughage for dairy heifers. R Bras Zootec. 2017;46:80-4. https://doi.org/10.1590/ s1806-92902017000100012

2. Costa DA, Clebson SL, Eloísa SSO, Jailton CC. By-products of sugar cane industry in ruminant nutrition. International J Adv Agric Res. 2015;3:1-9. https://doi.org/10.33500/ ijaar.2015.03.001

3. Chen XZ, Li WY, Gao CF, Zhang XP, Weng BQ, Cai YM. Silage preparation and fermentation quality of kudzu, sugarcane top and their mixture treated with lactic acid bacteria, molasses and cellulase. Anim Sci J. 2017;88:1715-21. https://doi.org/10.1111/asj.12840

4. Śliwiński B, Brzóska F, Węglarzy K, Bereza M. Effect of silage from maize and strip-cropped sorghum and maize on dairy cow's yield and milk composition. Ann Anim Sci. 2012;12:36779. https://doi.org/10.2478/v10220-012-0031-5

5. Khota W, Pholsen S, Higgs D, Cai YM. Fermentation quality and in vitro methane production of sorghum silage prepared with cellulase and lactic acid bacteria. Asian-Australas J Anim Sci. 2017;30:1568-74. https://doi.org/10.5713/ajas.16.0502

6. Wang S, Guo G, Li JF, Chen L, Dong ZH, Shao T. Improvement of fermentation profile and structural carbohydrate compositions in mixed silages ensiled with fibrolytic enzymes, molasses and Lactobacillus plantarum MTD-1. Ital J Anim Sci. 2019;18:328-35. https://doi.org/10.108 0/1828051X.2018.1528899

7. Li J, Shen YX, Cai YM. Improvement of fermentation quality of rice straw silage by application of a bacterial inoculant and glucose. Asian-Australas J Anim Sci. 2010;23:901-6. https:// doi.org/10.5713/ajas.2010.90403

8. Pholsen S, Khota W, Pang H, Higgs D, Cai Y. Characterization and application of lactic acid bacteria for tropical silage preparation. Anim Sci J. 2016;87:1202-11. https://doi.org/10.1111/ asj.12534

9. Cherdthong A, Suntra C, Khota W. Improving nutritive value of ensiled rice straw as influenced by Lactobacillus casei. Khon Kaen Agric J. 2019;47 suppl 1:s105-10.

10. AOAC [Association of Official Analytical Chemists]. Official methods of analysis. 15 th ed. Arlington, VA: Association of Official Analytical Chemists; 1990.

11. Van Soest PJ, Robertson JB, Lewis BA. Methods for dietary fiber, neutral detergent fiber, and nonstarch polysaccharides in relation to animal nutrition. J Dairy Sci. 1991;74:358397. https:// doi.org/10.3168/jds.S0022-0302(91)78551-2

12. Faichney GJ, White G. Methods for the analysis of feeds eaten by ruminants. Melbourne: Commonwealth Scientific and Industrial Research Organization; 1983.

13. Pruksatrakul T, Phoopra-in P, Jaiyen P, Vilairat P, Jantiwas R. Application of 2-step extraction method for determination of lactic acid in wastewater. Oral session presented at: The National and International Conference \& Research Presentation 2015; 2015 Jun 18-19; Nakhonratchasima, Thailand.

14. Mathew S, Sagathewan S, Thomas J, Mathen G. An HPLC method for estimation of volatile fatty acids of ruminal fluid. Indian J Anim Sci. 1997;67:805-7. 
15. Fawcett JK, Scott JE. A rapid and precise method for the determination of urea. J Clin Pathol. 1960;13:1569. https://doi.org/10.1136/jcp.13.2.156

16. Luangkriangkrai S, Inprasit C. Determination of ethanol in fermented media by head spacethe internal standard method in gas chromatography. Oral session presented at: The 8th Kasetsart University Kamphaeng Saen Campus Conference 2011; 2011 Dec 8-9; Nakhon Pathom, Thailand.

17. Kozaki M, Uchimura T, Okada S. Experimental manual for lactic acid bacteria. Tokyo, Japan: Asakurasyoten; 1992.

18. Steel RGD, Torrie JH. Principles and procedures of statistics. New York, NY: McGraw Hill; 1980.

19. Nkosi BD, Meeske R. Effects of ensiling totally mixed potato hash ration with or without a heterofermentative bacterial inoculant on silage fermentation, aerobic stability, growth performance and digestibility in lambs. Anim Feed Sci Technol. 2010;161:38-48. https://doi. org/10.1016/j.anifeedsci.2010.07.015

20. McEniry J, O'Kiely P, Clipson NJW, Forristal PD, Doyle EM. The microbiological and chemical composition of silage over the course of fermentation in round bales relative to that of silage made from unchopped and precision-chopped herbage in laboratory silos. Grass Forage Sci. 2008;63:407-20. https://doi.org/10.1111/j.1365-2494.2008.00645.x

21. Muck RE, Nadeau EMG, McAllister TA, Contreras-Govea FE, Santos MC, Kung L Jr. Silage review: recent advances and future uses of silage additives. J Dairy Sci. 2018;101:3980-4000. https://doi.org/10.3168/jds.2017-13839

22. Yitbarek MB, Tamir B. Silage additives: review. Open J Appl Sci. 2014;4:258-74. https://doi. org/10.4236/ojapps.2014.45026

23. Khota W, Pholsen S, Higgs D, Cai YM. Natural lactic acid bacteria population of tropical grasses and their fermentation factor analysis of silage prepared with cellulase and inoculant. J Dairy Sci. 2016;99:9768-81. https://doi.org/10.3168/jds.2016-11180

24. Hou ML, Gentu G, Liu TY, Jia YS, Cai YM. Silage preparation and fermentation quality of natural grasses treated with lactic acid bacteria and cellulase in meadow steppe and typical steppe. Asian-Australas J Anim Sci. 2017;30:788-96. https://doi.org/10.5713/ajas.16.0578

25. Gado HM, Elghandour MMY, Cipriano M, Odongo NE, Salem AZM. Rumen degradation and nutritive utilization of wheat straw, corn stalks and sugarcane bagasse ensiled with multienzymes.J Appl Anim Res. 2017;45:485-9. https://doi.org/10.1080/09712119.2016.1217866

26. Tian J, Yu Y, Yu Z, Shao T, Na R, Zhao M. Effects of lactic acid bacteria inoculants and cellulase on fermentation quality and in vitro digestibility of Leymus chinensis silage. Grassl Sci. 2014;60:199-205. https://doi.org/10.1111/grs.12059

27. Kim JG, Ham JS, Li YW, Park HS, Huh C, Park BC. Development of a new lactic acid bacterial inoculant for fresh rice straw silage. Asian-Australas J Anim Sci. 2017;30:950-6. https:// doi.org/10.5713/ajas.17.0287

28. Zahiroddini H, Baah J, Absalom W, McAllister T. Effect of an inoculant and hydrolytic enzymes on fermentation and nutritive value of whole crop barley silage. Anim Feed Sci Technol. 2004;117:317-30. https://doi.org/10.1016/j.anifeedsci.2004.08.013

29. Derwhust RJ, Webster AJF, Wainman FW, Dewey PJS. Prediction of the true metabolizable energy concentration in forages for ruminants. Anim Sci. 1986;43:183-94. https://doi. org/10.1017/S0003356100002361

30. McDonald P, Henderson A, Ralton I. Energy changes during ensilage. J Sci Food Agric. 1973;24:827-34. https://doi.org/10.1002/jsfa.2740240711

31. Yang FY, Wang CJ. Thremmatology of herbivore. Beijing: Agricultural Science and Technolo- 
gy Press of China; 2016.

32. McDonald P, Henderson AR, Heron SJE. The biochemistry of silage. Marlow: Chalcombe Publications; 1991.

33. Yang G, Zang Y, Jiang Z, Han Y, Hou J, Liu H, et al. Fermentation quality and nutritive value of fresh and fermented total mixed rations containing Chinese wildrye or corn stover. Grassl Sci. 2016;62:213-23. https://doi.org/10.1111/grs.12134

34. Li M, Zi XJ, Zhou HL, Hou GY, Cai YM. Effects of sucrose, glucose, molasses and cellulase on fermentation quality and in vitro gas production of king grass silage. Anim Feed Sci Technol. 2014;197:206-12. https://doi.org/10.1016/j.anifeedsci.2014.06.016

35. Zhang Q, Yu Z, Yang H, Na RS. The effects of stage of growth and additives with or without cellulase on fermentation and in vitro degradation characteristics of Leymus chinensis silage. Grass Forage Sci. 2015;71:595-606. https://doi.org/10.1111/gfs.12210

36. Weiss K, Kroschewski B, Auerbach H. Effects of air exposure, temperature and additives on fermentation characteristics, yeasts count, aerobic stability and volatile organic compounds in corn silage. J Dairy Sci. 2016;99:8053-69. https://doi.org/10.3168/jds.2015-10323

37. Wang C, Nishino N. Effects of storage temperature and ensiling period on fermentation products, aerobic stability and microbial communities of total mixed ration silage.J Appl Microbiol. 2013;114:1687-95. https://doi.org/10.1111/jam.12200

38. Zhou Y, Drouin P, Lafrenière C. Effect of temperature $\left(5-25^{\circ} \mathrm{C}\right)$ on epiphytic lactic acid bacteria populations and fermentation of whole-plant corn silage. J Appl Microbiol. 2016;121:65771. https://doi.org/10.1111/jam.13198

39. Xing L, Chen LJ, Han LJ. The effect of an inoculant and enzymes on fermentation and nutritive value of sorghum straw silages. Bioresour Technol. 2009;100:48891. https://doi. org/10.1016/j.biortech.2008.06.017

40. Muck RE. Factors influencing silage quality and their implications for management. J Dairy Sci. 1988;71:2992-3002. https://doi.org/10.3168/jds.S0022-0302(88)79897-5

41. Li Y, Nishino N. Effects of ensiling fermentation and aerobic deterioration on the bacterial community in Italian ryegrass, guinea grass, and wholecrop maize silages stored at high moisture content. Asian-Australas J Anim Sci. 2013;6:130412. https://doi.org/10.5713/ ajas.2013.13175

42. Cao Y, Cai Y, Takahashi T, Yoshida N, Tohno M, Uegaki R, et al. Effect of lactic acid bacteria inoculant and beet pulp addition on fermentation characteristics and in vitro ruminal digestion of vegetable residue silage.J Dairy Sci. 2011;94:390212. https://doi.org/10.3168/jds.2010-3623

43. Seok JS, Kim YI, Lee YH, Choi DY, Kwak WS. Effect of feeding a by-product feed-based silage on nutrients intake, apparent digestibility, and nitrogen balance in sheep.J Anim Sci Technol. 2016;58:9. https://doi.org/10.1186/s40781-016-0091-7 